\section{Developmental Stage and Growth Regulator Concentration Differentially Affect Vegetative Propagation of Select Clones of Taxodium Rich.}

\author{
Andrew R. King ${ }^{1,5}$ and Michael A. Arnold ${ }^{2}$ \\ Texas A\&M University, Department of Horticultural Sciences, HFSB 201, \\ College Station, TX 77843-2133
}

\author{
Douglas F. Welsh ${ }^{3}$ \\ Texas AgriLife Extension Service, College Station, TX 77843-2134
}

\author{
W. Todd Watson ${ }^{4}$ \\ Texas A\&M University, Department of Ecosystem Science and Management, \\ College Station, TX 77843-2138
}

Additional index words. Taxodium distichum, rooted cuttings, adventitious rooting, IBA, vegetative propagation

Abstract. In previous studies, baldcypress [Taxodium distichum (L.) Rich.] clones were selected for improved field tolerance to alkaline soils, drought, foliar or soil salinity exposure, and for ornamental traits. Objectives of the current research were to 1) determine the clonal responses to potassium salt of indole-3-butyric acid (K-IBA) across seasonal developmental stages of cuttings; and 2) to determine whether rooting and callus percentages and rooted cutting quality (root number, length, and mass) would be sufficient for commercial production should these clones be released to industry. Cuttings were taken from 24 clones at three distinct stages of stem maturity (softwood, semihardwood, and hardwood). Three concentrations of $\mathrm{K}$-IBA were tested $\left[0,7,500\right.$, and $15,000 \mathrm{mg} \cdot \mathrm{L}^{-1}$ $(0,31.1,62.2 \mathrm{~mm}$, respectively)] on each clone at each stage. Rooting percentages ranged from $\approx 94 \%$ (clone MX1MC33) at the softwood stage to $0 \%$ for several clones at the hardwood stage. Some clones such as MX5MC17 rooted at statistically similar percentages in the softwood and semihardwood stages $(88 \%$ and $83 \%$, respectively). Clone EP3DC16 rooted at low levels (less than $20 \%)$ in all stages. Significant $(P \leq 0.05)$ interactions occurred between growth stage and clone in some cases. Clone EP8DC14 rooted at 59\% at the softwood stage but only $37 \%$ at the semihardwood stage. Root number and length exhibited three-way interactions $(P \leq 0.05)$ among clone, developmental stage, and K-IBA concentration. Mean total root length ranged from $2 \mathrm{~cm}$ per cutting on semihardwood cuttings of MX2MC31 treated with no growth regulator to $81 \mathrm{~cm}$ per cutting on softwood cuttings of TX8DC38 treated with $7500 \mathrm{mg} \cdot \mathrm{L}^{-1} \mathrm{~K}-\mathrm{IBA}$. Mean root length varied from $2 \mathrm{~cm}$ for several clones at the semihardwood stage to $11 \mathrm{~cm}$ for softwood cuttings of MX2MC31 treated with $15,000 \mathrm{mg} \cdot \mathrm{L}^{-1} \mathrm{~K}-\mathrm{IBA}$. The greatest rooting percentages across K-IBA concentrations were typically at the softwood stage. Cuttings treated with either 7,500 or $15,000 \mathrm{mg} \cdot \mathrm{L}^{-1} \mathrm{~K}-\mathrm{IBA}$ rooted at the greatest percentages across stem maturity stages. No clone rooted well in the hardwood stage. The high concentration of $K-\operatorname{IBA}\left(15,000 \mathrm{mg} \cdot \mathrm{L}^{-1}\right)$ sometimes induced basal stem damage.

Received for publication 12 Sept. 2011. Accepted for publication 30 Nov. 2011.

This work was supported in part by funds from Texas AgriLife Research.

Mention of a trademark, proprietary product, or vendor does not constitute a guarantee or warranty of the product by the authors, Texas A\&M University, or Texas AgriLife Research and does not imply its approval to the exclusion of other products or vendors that also may be suitable.

This study was included as part of a thesis written in partial fulfillment of the requirements for the MS degree by A.R. King.

${ }^{1}$ Research Associate and Graduate Student.

${ }^{2}$ Professor.

${ }^{3}$ Professor and Associate Department Head.

${ }^{4}$ Adjunct Professor.

${ }^{5}$ To whom reprint requests should be addressed; e-mail aking@tamu.edu. do affect its growth. Taxodium displays stressinduced responses when grown in high $\mathrm{pH}$ soils, exposed to prolonged drought, or when salt-laden spray from irrigation contacts the foliage (Arnold, 2008; Denny, 2007; Dirr, 2009). Denny (2007) conducted provenance screenings for tolerance to these stresses and recommended that studies be conducted on asexual propagation by cuttings of subsequent clonal selections.

Taxodium is typically commercially propagated in one of three ways. It is grown from seed, grafted, or produced by cuttings. Baldcypress seeds are easily germinated with proper stratification; however, seedling material lacks uniformity (Dirr, 2009; Pezeshki and DeLaune, 1994). Grafting is a reliable but more expensive method of propagating baldcypress (Dirr, 2009; Thomsen, 1978). Alternatively, vegetative propagation by cuttings yields uniform plants and through selection can be used to expedite narrow sense heritable genetic improvement in this species (Pezeshki and DeLaune, 1994). Previous studies have shown relatively high percentages of rooting for Taxodium cuttings (Copes and Randall, 1993; King, 2010; Pezeshki and DeLaune, 1994; St. Hilaire, 2003; Zhou, 2005), supporting further commercialization of the practice.

Copes and Randall (1993) reported 58\% rooting of baldcypress when using 3-year-old ramets that were initially taken from 20 -yearold ortets. The authors attributed this higher percentage to the $50 \%$ moisture content of the rooting substrate, which was the wettest tested. Pezeshki and DeLaune (1994) found that the rooting percentage of hardwood baldcypress cuttings decreased significantly $(P \leq 0.05)$ when cuttings were taken from branch tips of 25- to 50-year-old trees vs. 1-year-old trees. When the cuttings taken from the 1-yearold trees were treated with a $1000 \mathrm{mg} \cdot \mathrm{kg}^{-1}$ powder form of indole-3-butyric acid (IBA) (ROOTONE®; Ferti-lome Co., Bonham, TX), they rooted at a similar percentage as those that received no IBA. Cuttings treated with IBA had significantly greater $(P \leq 0.05)$ shoot dry weights (Pezeshki and DeLaune, 1994). This is in contrast to the results of St. Hilaire (2003) who found that softwood cuttings of T. distichum var. mexicanum showed an increase in rooting percentage with increasing concentrations of IBA. In 1 year of the study, rooting percentages were $48 \%$ and $82 \%$ for 3000 and $8000 \mathrm{mg} \cdot \mathrm{L}^{-1}$ IBA, respectively. Cuttings over all treatment combinations rooted at an average of $65 \%$ the first year and $10 \%$ the next year. This indicates that the age of the ortet may be a limiting factor in successful propagation. This result agrees with the previously discussed study by Pezeshki and DeLaune (1994). Zhou (2005) reported that rooting percentages increased for a baldcypress clone T302 (T. distichum var. distichum $\times T$. distichum var. mexicanum) with the application of increasing levels of K-IBA. Cuttings treated with 5,000 and $10,000 \mathrm{mg} \cdot \mathrm{L}^{-1} \mathrm{~K}-\mathrm{IBA}$ rooted at $57.6 \%$ and $68.1 \%$, respectively. Cuttings treated with 0 and $2500 \mathrm{mg} \cdot \mathrm{L}^{-1} \mathrm{~K}$-IBA rooted at the significantly lower $(P \leq 0.05)$ rates of $16.6 \%$ and $22.2 \%$, respectively (Zhou, 2005). 
The objective of the current study was to determine the clonal responses to K-IBA across seasonal developmental stages of cuttings and to determine whether rooting and callus percentages and rooted cutting quality (root number, length, and mass) would be sufficient for commercial production should these clones be released to industry.

\section{Materials and Methods}

Clones tested were identified as having commercial potential based on previous work (Denny, 2007). Twenty-four clones were derived from 13 open-pollinated, half-sib families within provenances of $T$. distichum ranging from the central to the western and southwestern portions of the species' native range (Table 1). The first two characters in the identification code for each clone indicate eastern (EP), central Texas (TX), or south Texas to Mexican (MX) provenances. The third character is a family number within the provenance and the fourth character designates the botanical variety $(\mathrm{D}=T$. distichum var. distichum, $\mathrm{I}=T$. distichum var. imbricarium, $\mathrm{M}=T$. distichum var. mexicanum) (Table 1). In subsequent text and figures these codes followed by the letter $\mathrm{C}$ and a one- or two-digit number indicate individual clones within those families.

Terminal shoot tip cuttings were taken from baldcypress selections grown in a research plot at Texas A\&M University, College Station, TX (lat. 30³7'645" N, long. 96 $22^{\prime} 319^{\prime \prime} \mathrm{W}$ ) or at the Texas AgriLife Research/Extension Center in Dallas, TX (lat. 32 $59^{\prime} 013^{\prime \prime} \mathrm{N}$, long. $96^{\circ} 46^{\prime} 004^{\prime \prime} \mathrm{W}$ ). All cuttings of a clone were harvested from the original seedling selection (original plant selected to become a clonal selection) and all were 4 years old. In an effort to test different stages of stem maturity, cuttings were taken at three times during the year. Softwood cuttings were taken from the College Station site on 16 May 2008 and from the Dallas site on 19 May 2008. Semihardwood cuttings were taken from Dallas on 24 July 2008 and from College Station on 28 July 2008. Hardwood cuttings were taken from Dallas on 7 Jan. 2009 and from College Station on 8 Jan. 2009. All cuttings, except those taken from the College Station site on 16 May 2008, were kept overnight in a cooler at $8-9^{\circ} \mathrm{C}$ to ensure hydration. Cuttings were stuck (planting the unrooted basal end in the substrate) the next day. Before planting, cuttings were trimmed and treated with 0 (control), 7,500, or 15,000 $\mathrm{mg} \cdot \mathrm{L}^{-1}(0,31.1,62.2 \mathrm{~mm}$, respectively) K-IBA (Sigma-Aldrich Chemical, St. Louis, MO). Mean cutting length was $12.5 \mathrm{~cm}$. The basal end of each cutting was submerged $5 \mathrm{~cm}$ deep into the test solution for $5 \mathrm{~s}$. Cuttings were stuck $5 \mathrm{~cm}$ deep in a 1.5:1 peat:perlite (Sunshine ${ }^{\circledR}$ Peat Moss; Sunshine ${ }^{\circledR}$ Strong Lite coarse grade perlite; Sun Gro ${ }^{\circledR}$ Horticulture, Seba Beach, Alberta, Canada) substrate by volume, in $10 \mathrm{~cm}$ tall $\times 36 \mathrm{~cm}$ wide $\times 51-\mathrm{cm}$ long black plastic flats (Dyna-flat ${ }^{\top \mathrm{M}}$; Kadon Corp., Dayton, OH). Cuttings were placed on 1-m tall benches in a greenhouse in a modified randomized completed block design. Each factorial combination of clone, K-IBA concentration, and stem maturity was tested on 30 cuttings, 10 in each of three blocks, which yielded 6480 total cuttings. Reverse osmosis water was misted intermittently through high-pressure mist nozzles for a period of $10 \mathrm{~s}$ on a 16-min cycle during the daylight hours. Average substrate temperatures were measured with the Omega ${ }^{\circledR}$ HH309 Data Loggerthermometer (Omega Engineering, Inc., Stamford, CT). Photosynthetically active radiation was measured with a ceptometer (AccuPAR; Decagon Devices, Inc., Pullman, WA).

Cuttings were allowed to root for 8 weeks and then destructively harvested. Softwood, semihardwood, and hardwood treatments were harvested 14 to 21 July, 22 Sept. to 2 Oct., and 9 to 16 Mar., respectively. Data collected from each cutting included determinations of callus tissue formation, adventitious root formation, and the number of roots produced per cutting. From each replicate treatment combination, five rooted cuttings were randomly selected from which total and mean root length and root and shoot dry mass were measured. In replicate treatment combinations that did not yield five rooted cuttings, cuttings that did root were preferentially selected along with randomly selected unrooted cuttings until five samples were obtained. To ensure accurate estimates of adventitious root quality, unrooted cuttings used for data collection were not included in mean estimations of root quality parameters (root number per cutting, root dry mass, or total and average root length). As a result of low rooting levels in hardwood cuttings, the cuttings that were not selected for destructive measurements were returned to the mist bed for an additional 4 weeks to determine whether adventitious rooting would increase with time. Possible interactions among the clone propagated, K-IBA concentration tested, and stage of cutting maturation were analyzed using the General Linear Models Procedures in SAS in a stepwise fashion beginning with the highest order interactions and progressing to the main effects if an effect was not significant in a higher order interaction. Means were compared using least squared means procedures (SAS 9.1 for Windows; SAS Institute, Cary, NC).

\section{Results and Discussion}

Environmental conditions in the mist bench varied somewhat on a seasonal basis. Photosynthetically active radiation measurements at the canopy level were $403.1 \mu \mathrm{mol} \cdot \mathrm{m}^{-2} \cdot \mathrm{s}^{-1}$, $461.1 \mu \mathrm{mol} \cdot \mathrm{m}^{-2} \cdot \mathrm{s}^{-1}$, and $284.7 \mu \mathrm{mol} \cdot \mathrm{m}^{-2} \cdot \mathrm{s}^{-1}$ for the softwood, semihardwood, and hardwood treatments, respectively. Mean temperatures in the rooting substrates were 29.5, 27.0 , and $20.6{ }^{\circ} \mathrm{C}$ for the softwood, semihardwood, and hardwood treatments, respectively.

Significant two-way interactions (Table 2) were present for rooting percentage and callus percentage $(P \leq 0.0001$ and $P \leq 0.05$, respectively), whereas significant $(P \leq 0.01)$ three-way interactions were shown for all root quality measurements (root number, root length, and root dry mass). All parameters measured, except mean root length, were significantly affected by the main effects of K-IBA concentration, stage of cutting development, and clone propagated (Table 2).

An analysis of variance of mean rooting and callus percentages indicated significant interactions between the stage of development and clone propagated $(P \leq 0.0001$ and $P \leq 0.0001$ for root percentage and callus percentage, respectively) and between the

Table 1. Localities of provenances of baldcypress used for propagation testing. ${ }^{z}$

\begin{tabular}{llll}
\hline Open-pollinated family & \multicolumn{1}{c}{ Latitude } & \multicolumn{1}{c}{ Longitude } & \multicolumn{1}{c}{ Locale } \\
\hline EP8D & $31^{\circ} 33^{\prime} 36^{\prime \prime} \mathrm{N}$ & $91^{\circ} 26^{\prime} 24^{\prime \prime} \mathrm{W}$ & Mississippi River, LA \\
EP7D & $30^{\circ} 23^{\prime} 24^{\prime \prime} \mathrm{N}$ & $88^{\circ} 55^{\prime} 48^{\prime \prime} \mathrm{W}$ & Biloxi, MS \\
EP5I & $30^{\circ} 27^{\prime} 0^{\prime \prime} \mathrm{N}$ & $88^{\circ} 6^{\prime} 36^{\prime \prime} \mathrm{W}$ & Fowl River, AL \\
EP3D & $29^{\circ} 5^{\prime} 24^{\prime \prime} \mathrm{N}$ & $91^{\circ} 12^{\prime} 6^{\prime \prime} \mathrm{W}$ & Bayou Teche, LA \\
EP2D & $29^{\circ} 48^{\prime} 0^{\prime \prime} \mathrm{N}$ & $91^{\circ} 47^{\prime} 24^{\prime \prime} \mathrm{W}$ & Iberia Parish, LA \\
EP1D & $32^{\circ} 20^{\prime} 24^{\prime \prime} \mathrm{N}$ & $94^{\circ} 42^{\prime} 0^{\prime \prime} \mathrm{W}$ & Lake Cherokee, TX \\
TX3D & $29^{\circ} 47^{\prime} 24^{\prime \prime} \mathrm{N}$ & $99^{\circ} 35^{\prime} 24^{\prime \prime} \mathrm{W}$ & Sabinal River, TX \\
TX8D & $29^{\circ} 52^{\prime} 48^{\prime \prime} \mathrm{N}$ & $97^{\circ} 55^{\prime} 48^{\prime \prime} \mathrm{W}$ & San Marcos River, TX \\
MX1M & $25^{\circ} 52^{\prime} 48^{\prime \prime} \mathrm{N}$ & $97^{\circ} 27^{\prime} 0^{\prime \prime} \mathrm{W}$ & Southmost, TX \\
MX2M & $25^{\circ} 18^{\prime} 36^{\prime \prime} \mathrm{N}$ & $104^{\circ} 38^{\prime} 24^{\prime \prime} \mathrm{W}$ & Rio Nazas, MX \\
MX4M & $27^{\circ} 51^{\prime} 0^{\prime \prime} \mathrm{N}$ & $101^{\circ} 7^{\prime} 48^{\prime \prime} \mathrm{W}$ & Rio Sabinas, MX \\
MX5M & $26^{\circ} 4^{\prime} 12^{\prime \prime} \mathrm{N}$ & $97^{\circ} 54^{\prime} 36^{\prime \prime} \mathrm{W}$ & Progreso, TX \\
MX6M & $-\mathrm{y}$ & - & \\
\hline
\end{tabular}

${ }^{\mathrm{z}}$ Adapted from Denny (2007).

$y_{-}=$Location of the provenance is uncertain.

Table 2. Levels of significance of analysis of variance for select rooting parameters and shoot dry mass.

\begin{tabular}{lccccccc}
\hline Source of variation & $\begin{array}{c}\text { Rooting } \\
\%\end{array}$ & $\begin{array}{c}\text { Callus } \\
\%\end{array}$ & $\begin{array}{c}\text { Root } \\
\text { number }\end{array}$ & $\begin{array}{c}\text { Total } \\
\text { root length }\end{array}$ & $\begin{array}{c}\text { Mean root } \\
\text { length }\end{array}$ & $\begin{array}{c}\text { Root dry } \\
\text { mass }\end{array}$ & $\begin{array}{c}\text { Shoot dry } \\
\text { mass }\end{array}$ \\
\hline Stage & $* * * * z$ & $* * * *$ & $* * * *$ & $* * * *$ & NS & $* * * *$ & $* * * *$ \\
Clone & $* * * *$ & $* * * *$ & $* * * *$ & $* * * *$ & $* * * *$ & $* * * *$ & $* * * *$ \\
Stage $\times$ clone & $* * * *$ & $* * * *$ & $* * * *$ & $* * * *$ & $* * * *$ & $* * * *$ & $* * * *$ \\
K-IBA concentration & $* * * *$ & $* * * *$ & $* * * *$ & $* * * *$ & $* * * *$ & $* * * *$ & NS \\
Stage $\times$ K-IBA conc. & $* * * *$ & $*$ & $* * * *$ & NS & NS & NS & NS \\
Clone $\times$ K-IBA conc. & NS & NS & $* * * *$ & $* * * *$ & $* *$ & $* * * *$ & $*$ \\
Stage $\times$ clone $\times$ K-IBA & NS & NS & $* * * *$ & $* *$ & $* *$ & $* *$ & $* *$ \\
\hline
\end{tabular}

${ }^{\mathrm{z}}$ Significant at $* P \leq 0.05, * * 0.01, * * * 0.001, * * * * 0.0001 ; \mathrm{NS}=$ nonsignificant at $P \leq 0.05$.

$\mathrm{K}$-IBA $=$ potassium salt of indole-3-butyric acid. 
stage of development and K-IBA concentration $(P \leq 0.0001$ and $P \leq 0.05$, respectively) (Table 2). For most clones (15 of 24 tested), the softwood stage of development produced a greater percentage of rooted cuttings (Fig. 1A-D). Cuttings tested in the semihardwood stage rooted at the same or lower percentages than those in the softwood stage with the exception of clone EP5IC13 (Fig. 1A). This clone was a selection of $T$. distichum var. imbricarium (Table 1), which rooted at $60 \%$ in the semihardwood stage and $36.6 \%$ in the softwood stage. Callus percentages, however, displayed no significant difference between softwood and semihardwood in 20 of the 24 clones (Fig. 2A-D). No clone had rooting percentages above $2 \%$ in the hardwood stage when averaged across K-IBA concentrations after 8 weeks in the mist bench. Callus percentages in the hardwood stage (Fig. 2), although significantly lower than the softwood and semihardwood stages, were generally much greater than the hardwood rooting percentages realized in the current research. The greater number of callused cuttings than rooted cuttings observed suggests a potential for improvement in rooting percentages of hardwood cuttings, because adventitious baldcypress roots emanate from cutting callus tissue (Jackson, 1986). Hardwood cuttings returned to the mist bench for an additional 4 weeks, however, did not root in increased numbers to any substantial extent (data not shown).

The interaction in rooting and callus percentages between stage of development and K-IBA concentration (Figs. 3A and 4A) appears to be an artifact resulting from the severe lack of adventitious rooting and decreased incidence of callus tissue formed in the hardwood stage of development. A supplemental analysis of rooting and callus percentage data omitting the hardwood stage showed no significant $(P>0.05)$ interaction among stage of development and K-IBA concentration. The main effect of K-IBA concentration on rooting and callus percentage indicated no significant difference $(P>0.05)$ between the 7,500 and $15,000 \mathrm{mg} \cdot \mathrm{L}^{-1}$ concentrations. The $0 \mathrm{mg} \cdot \mathrm{L}^{-1}$ control treatment produced significantly fewer callused (Fig. 4B) or rooted cuttings (Fig. 3B) than those treated with K-IBA. These results agree with those of St. Hilaire (2003) and Zhou (2005). Many cuttings treated with the $15,000 \mathrm{mg} \cdot \mathrm{L}^{-1}$ concentration exhibited tissue toxicity in basal portions, which in most cases did not prevent the cutting from rooting above the affected tissue. Typically the toxicity was manifested on the basal $5 \mathrm{~cm}$ of cuttings (portion dipped into K-IBA solution), which became necrotic followed by root formation at the lower-most portion of the remaining live tissue (Fig. 5).

Significant three-way interactions $(P \leq$ 0.01 ) were found among stage of development, K-IBA concentration, and the clone propagated for all root quality measurements and shoot dry mass (Table 2). The three-way interaction for number of roots per rooted cutting was highly significant $(P \leq 0.0001)$. Mean root number per cutting has been shown to be positively correlated with subsequent growth measurements in western hemlock [Tsuga heterophylla (Raf.) Sarg.] and eastern white pine (Pinus strobes L.) (Foster et al., 1985; Struve et al., 1984). In the current research of Taxodium, the greatest mean number of roots per rooted cutting was generally found on softwood cuttings from the south Texas and Mexico region when treated with either 7,500 or $15,000 \mathrm{mg} \cdot \mathrm{L}^{-1} \mathrm{~K}-\mathrm{IBA}$. Mean root number per cutting response was highly variable for
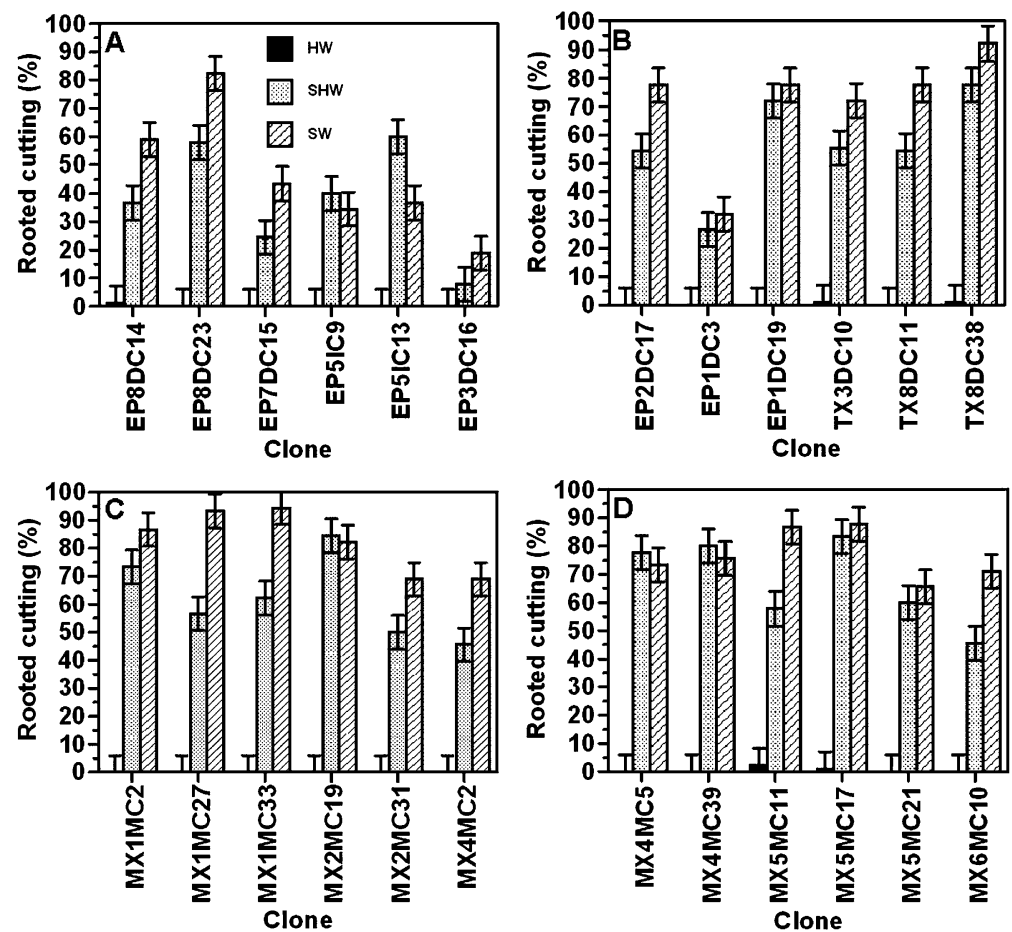

Fig. 1. Percentage of rooted cuttings for each of 24 clones in three developmental stages (softwood, semihardwood, and hardwood). Each graph contains clones from similar regional provenances: (A) clones from eastern provenances (EP), (B) three clones from eastern U.S. provenances (EP) and three clones from central Texas provenances (TX), $(\mathbf{C})$ clones from south Texas and Mexican provenances (MX), and (D) clones from south Texas and Mexican provenances, $\mathrm{n}=9$.
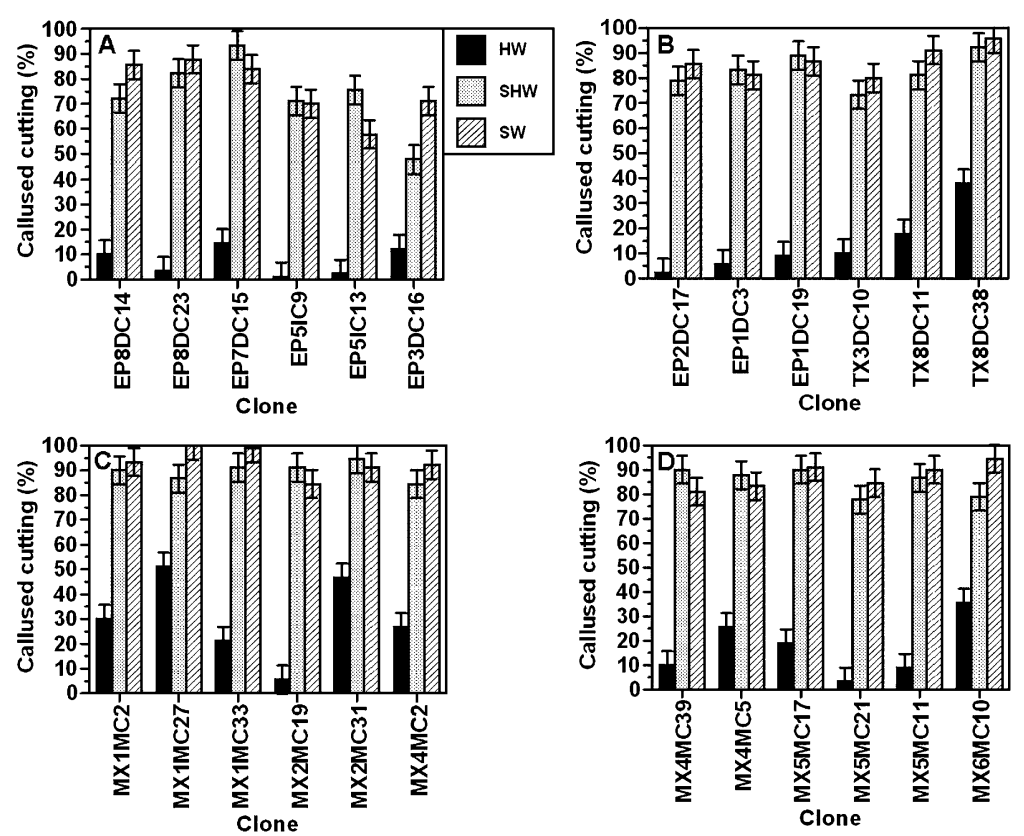

Fig. 2. Percentage of callused cuttings for each of 24 clones in three developmental stages (softwood, semihardwood, and hardwood). Each graph contains clones from similar regional provenances: (A) clones from eastern provenances (EP), (B) three clones from eastern U.S. provenances (EP) and three clones from central Texas provenances (TX), (C) clones from south Texas and Mexican provenances $(\mathrm{MX})$, and (D) clones from south Texas and Mexican provenances, $\mathrm{n}=9$. 

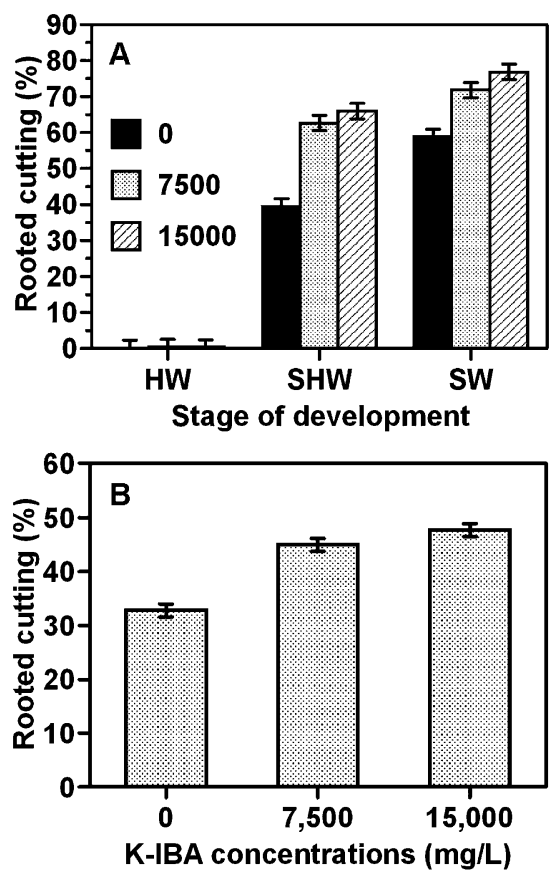

Fig. 3. Rooted cutting percentage for the interaction among stage of development (softwood, semihardwood, and hardwood) and potassium salt of indole-3-butyric acid (K-IBA) concentration (A), $\mathrm{n}=72$, and main effect of K-IBA $\left(0,7,500\right.$, and $\left.15,000 \mathrm{mg} \cdot \mathrm{L}^{-1}\right)$ concentration (B), $\mathrm{n}=216$.
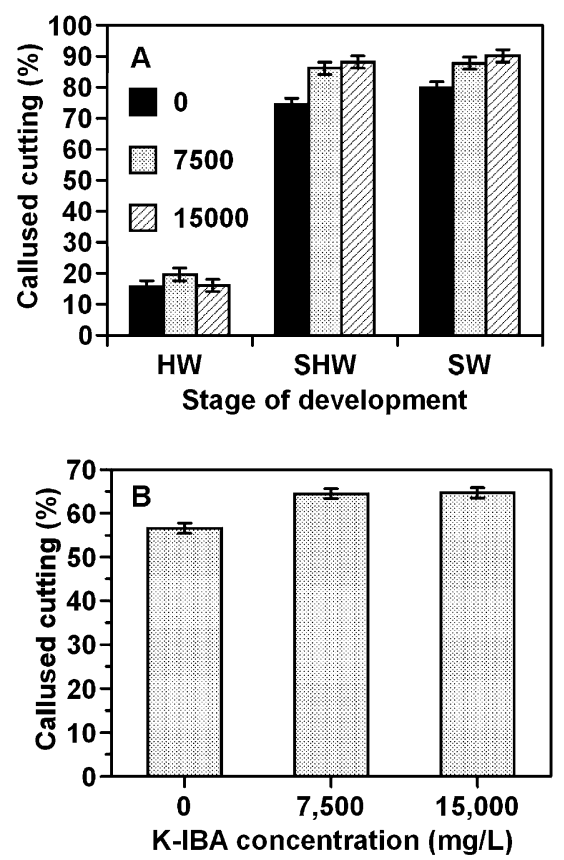

Fig. 4. Callused cutting percentage for the interaction among stage of development (softwood, semihardwood, and hardwood) and potassium salt of indole-3-butyric acid (KIBA) concentration (A), $\mathrm{n}=72$, and main effect of K-IBA $\left(0,7,500\right.$, and $\left.15,000 \mathrm{mg} \cdot \mathrm{L}^{-1}\right)$ concentration $(\mathbf{B}), \mathrm{n}=216$.

cuttings from central Texas provenances (Fig. $6 \mathrm{~J}-\mathrm{L})$. Cuttings from the clone TX3DC10 produced 0.8 roots per rooted cutting, whereas cuttings of TX8DC38 produced 3.5 roots per
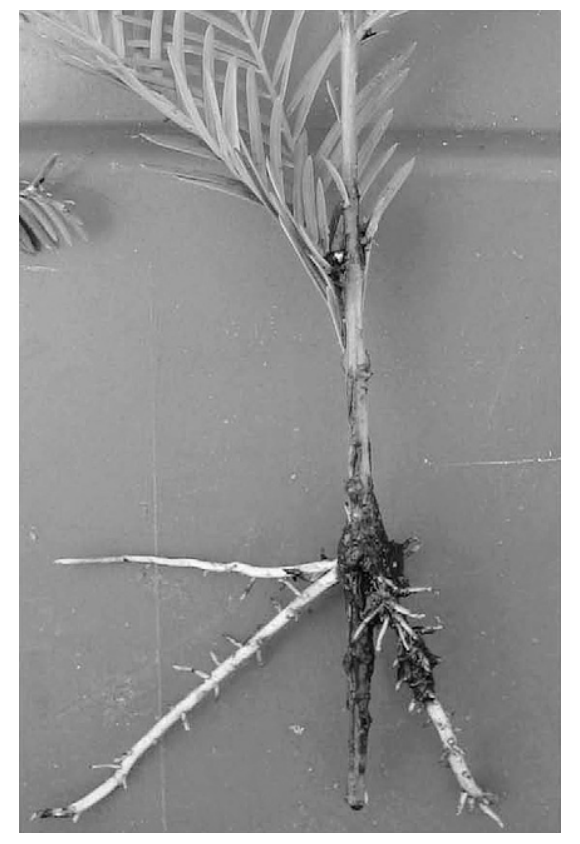

Fig. 5. Photograph shows the basal necrosis that occurred on some Taxodium cuttings treated with the highest concentration of potassium salt of indole-3-butyric acid (K-IBA) $\left(15,000 \mathrm{mg} \cdot \mathrm{L}^{-1}\right)$ tested. The necrosis prevented few cuttings from rooting however in most instances roots developed directly above the necrotic tissue.

rooted cutting on average. An increase in root number in response to basally applied K-IBA is consistent with St. Hilaire's (2003) results but contradicts results found in Pezeshki and DeLaune (1994). Pezeshki and DeLaune (1994) found that root number per cutting was not significantly $(P>0.05)$ affected by treatment with IBA. The root density ranking (RDR) discussed in Zhou (2005) included a qualitative measurement of root number per cutting; however, no direct quantitative measurements were given. Zhou's RDR followed the results found in the current research in that significantly greater root quality measurements were found on cuttings treated with higher concentrations of growth regulator $(10,000$ $\left.\mathrm{mg} \cdot \mathrm{L}^{-1} \mathrm{~K}-\mathrm{IBA}\right)$ than were exhibited in the control $\left(0 \mathrm{mg} \cdot \mathrm{L}^{-1} \mathrm{~K}\right.$-IBA). Very few roots per cutting were found in hardwood cuttings across all families and K-IBA concentrations (Fig. $6 \mathrm{~A}-\mathrm{X}$ ). Cuttings from the softwood and semihardwood stages when treated with $0 \mathrm{mg} \cdot \mathrm{L}^{-1}$ $\mathrm{K}$-IBA generally grew fewer roots per cutting than did the two greater concentrations across most families (Fig. 6). The exception was several eastern U.S. clones (Fig. 6A-F) and one central Texas clone, TX3DC10 (Fig. 6J), in which responses to K-IBA had a negligible effect. A geographic breakdown of the 24 families tested shows three relatively distinct groups (Fig. 6). The majority of clones from south Texas and Mexico (clonal designations beginning with $\mathrm{MX}$ ) were in the group that yielded the greatest number of roots per rooted cutting, whereas the bulk of the clones from eastern U.S. provenances (clonal designations beginning with EP) were found in the group that performed most poorly.
An intermediate group contained two south Texas/Mexico clones as well as a clone from the eastern provenances. Clones from central Texas provenances (clonal designations beginning with TX) were found in both the greatest and least roots per cutting groups. This distribution by provenance generally conforms to results found by Denny (2007) for regional variation in several stress tolerances associated with Taxodium. This regional association indicates that baldcypress cuttings taken from trees with more southerly and westerly provenances show more vigor in propagation than those taken from more eastern and northern provenances

Total and mean root length were also significantly affected $(P \leq 0.01)$ by three-way interactions among stage of development, $\mathrm{K}$ IBA concentration, and the clone propagated (Table 2). For both root length parameters measured, responses followed geographical gradient groupings reported by Denny (2007) for drought, soil alkalinity, and foliar salinity exposure responses. Cuttings from eastern provenances (Fig. 7A-I) had smaller total root lengths than most south Texas/Mexican provenances (Fig. 7M-X) and one of the central Texas selections, TX8DC38 (Fig. 7L). Statistically significant increases in total root length among K-IBA treatments within a clone from eastern U.S. provenances (Fig. 7A-I) were infrequent across stages of development. Central Texas propagules tended to follow the same trend as the eastern provenances, with the exception of TX8DC38, which had the greatest total root length among all clones tested (Fig. 7L). Total root length was generally greater in the south Texas and Mexican provenances, particularly in the softwood stage of development when treated with either 7,500 or $15,000 \mathrm{mg} \cdot \mathrm{L}^{-1} \mathrm{~K}-\mathrm{IBA}$ (Figs. 7M-Q, 7S, 7T, and $7 \mathrm{~V}$ ). A few clones (Figs. 7R, 7U, 7W, and $7 \mathrm{X}$ ) from the south Texas and Mexican provenances, however, had no greater total root length than the eastern U.S. provenances. Mean root length followed similar trends as those observed in total root length with minor variations (data not presented).

Significant three-way interactions $(P \leq$ 0.01) among stage of development, K-IBA concentration, and clone propagated were also observed for root and shoot dry mass (Table 2). Both dry mass parameters also displayed the aforementioned geographical gradient responses described in Denny (2007). Overall, the root dry mass parameter also trended in a similar fashion to total and mean root length where root dry mass was greater in the south Texas and Mexican provenances than in the eastern provenances (data not shown). Similar to the root length parameters, TX8DC38 was the clone from central Texas that had greater dry mass. Shoot dry mass however exhibited little consistent variability aside from the consistently less shoot mass found with hardwood cuttings in comparison with softwood or semihardwood cuttings (Fig. 8). This was likely because all hardwood cuttings were devoid of foliage. Consistent responses of shoot dry mass to K-IBA concentrations and softwood or semihardwood stages of 

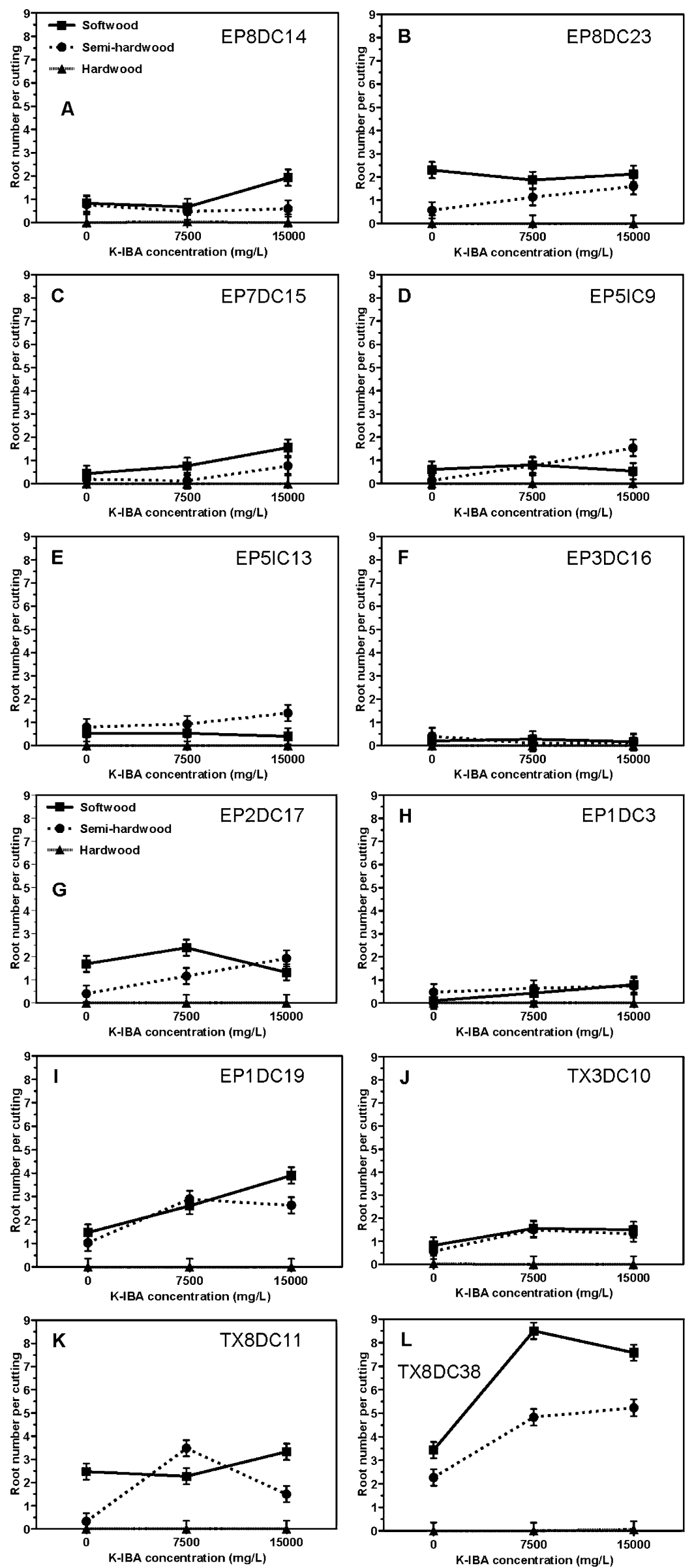

Fig. 6. Mean number of roots per cutting for the 24 clones across three stages of development and potassium salt of indole-3-butyric acid (KIBA) concentrations tested. A-I show the mean number of roots per cutting for clones from the eastern provenances (EP), J-L show the mean number of roots per cutting for the three clones from central Texas provenances (TX), M-X show the mean number of roots per cutting for clones from south Texas and Mexican provenances $(M X), n=3$. 

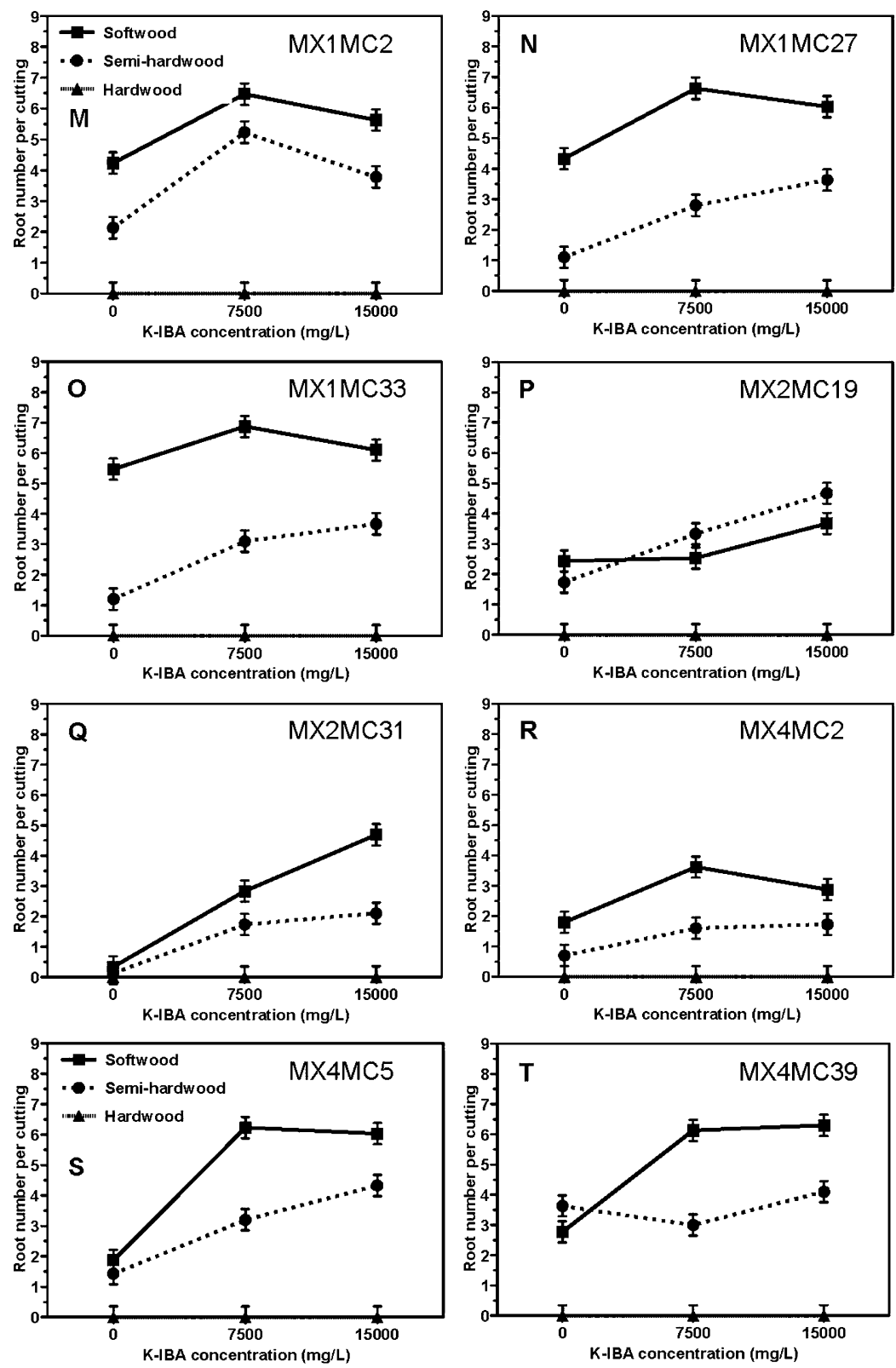

Fig. 6. (Continued)
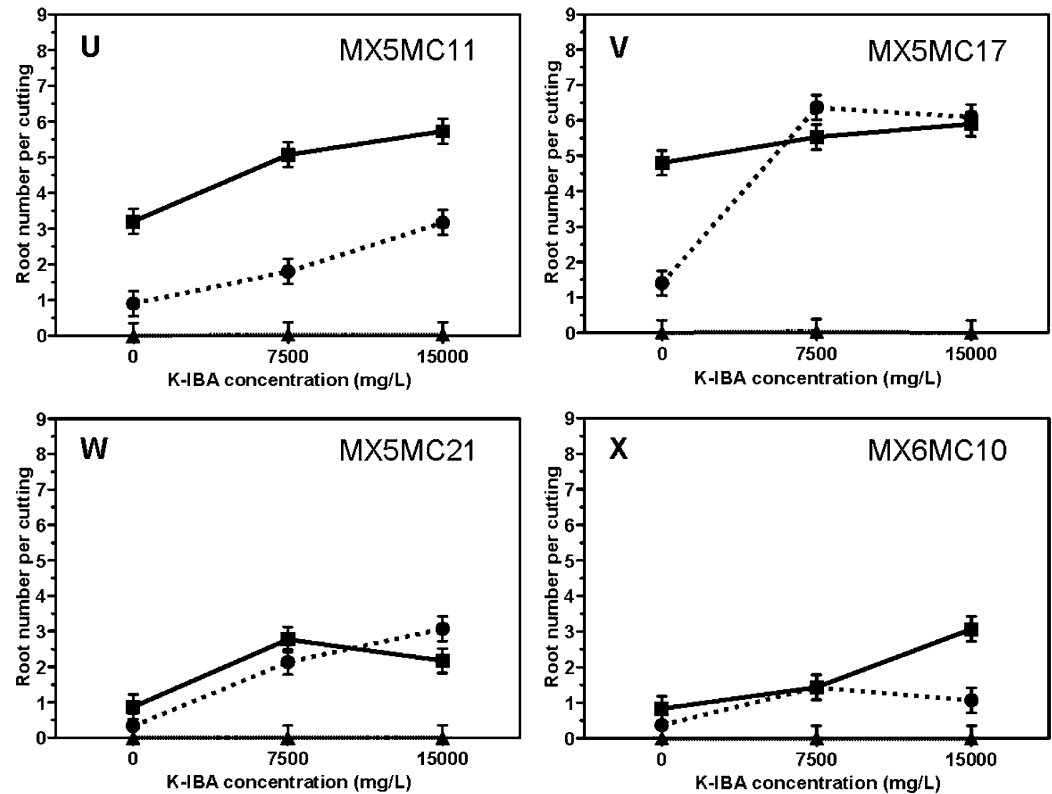

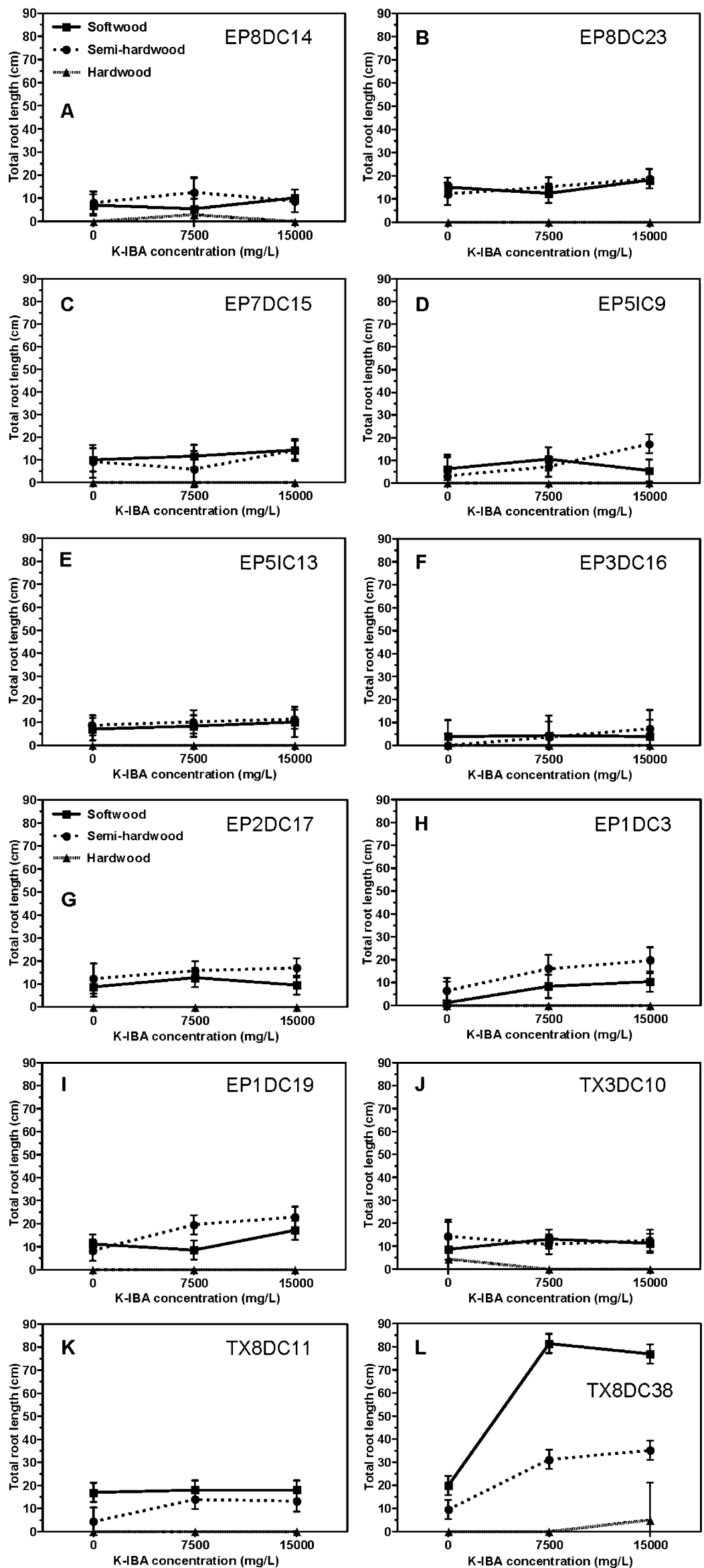

Fig. 7. Total root length $(\mathrm{cm})$ per cutting for the 24 clones across three stages of development and potassium salt of indole-3-butyric acid (KIBA) concentrations tested. A-I show the total root length $(\mathrm{cm})$ per cutting for clones from the eastern provenances (EP), J-L show the total root length $(\mathrm{cm})$ per cutting for the three clones from central Texas provenances (TX), M-X show the total root length $(\mathrm{cm})$ per cutting for clones from south Texas and Mexican provenances $(\mathrm{MX}), \mathrm{n}=3$. 

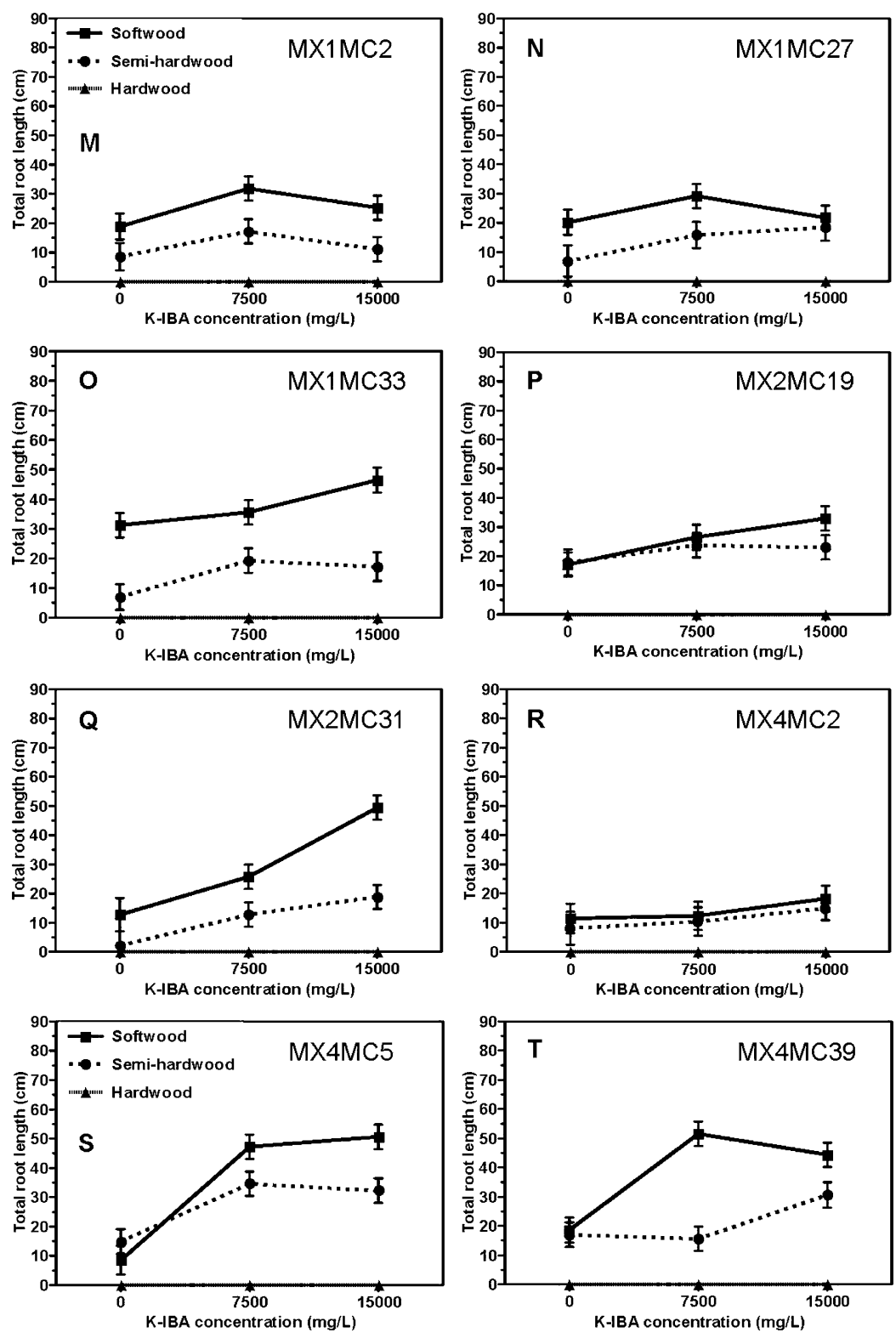

Fig. 7. (Continued)
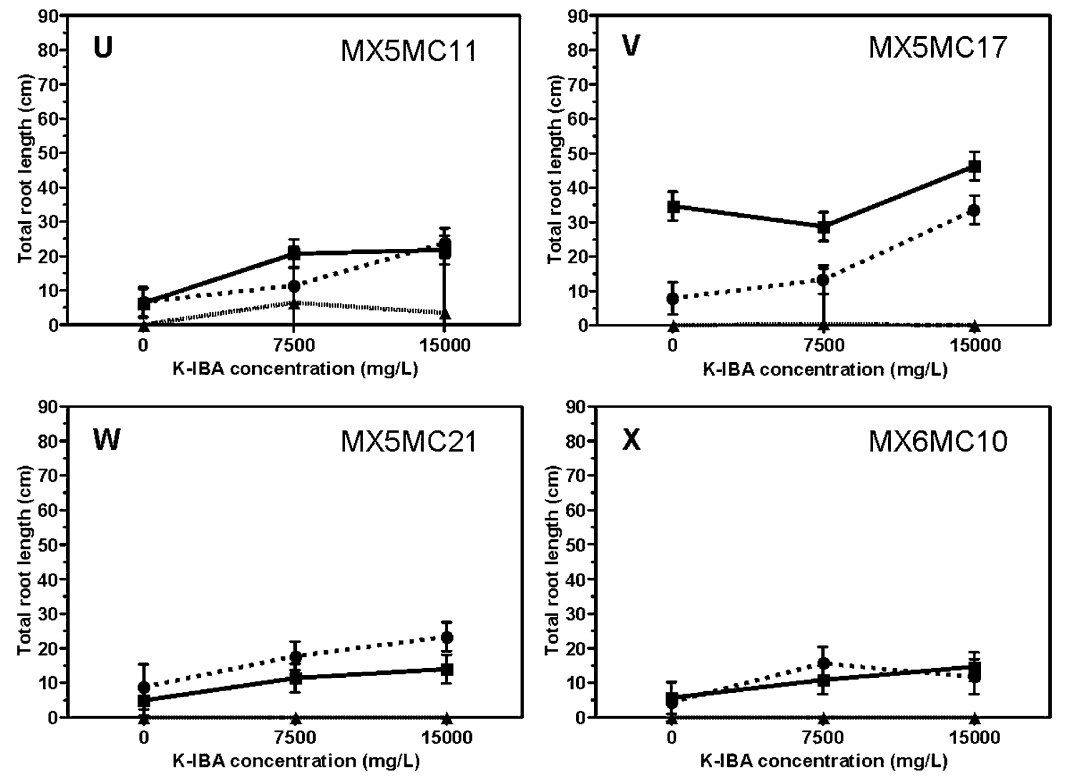

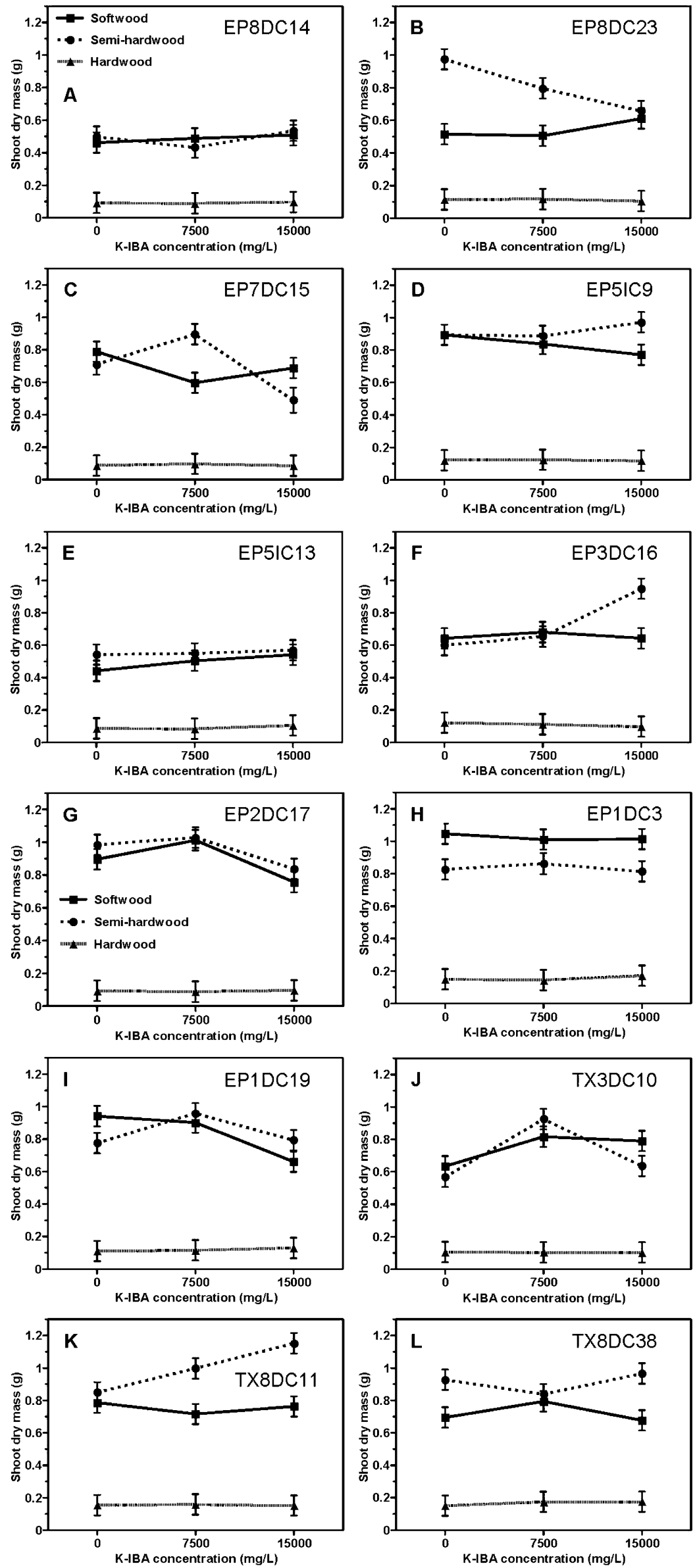

Fig. 8. Shoot dry mass (g) per cutting for the 24 clones across three stages of development and potassium salt of indole-3-butyric acid (KIBA) concentrations tested. A-I show the shoot dry mass $(\mathrm{g})$ per cutting for clones from the eastern provenances (EP), J-L show the shoot dry mass $(\mathrm{g})$ per cutting for the three clones from central Texas provenances (TX), M-X show the shoot dry mass (g) per cutting for clones from south Texas and Mexican provenances (MX), $\mathrm{n}=3$. 

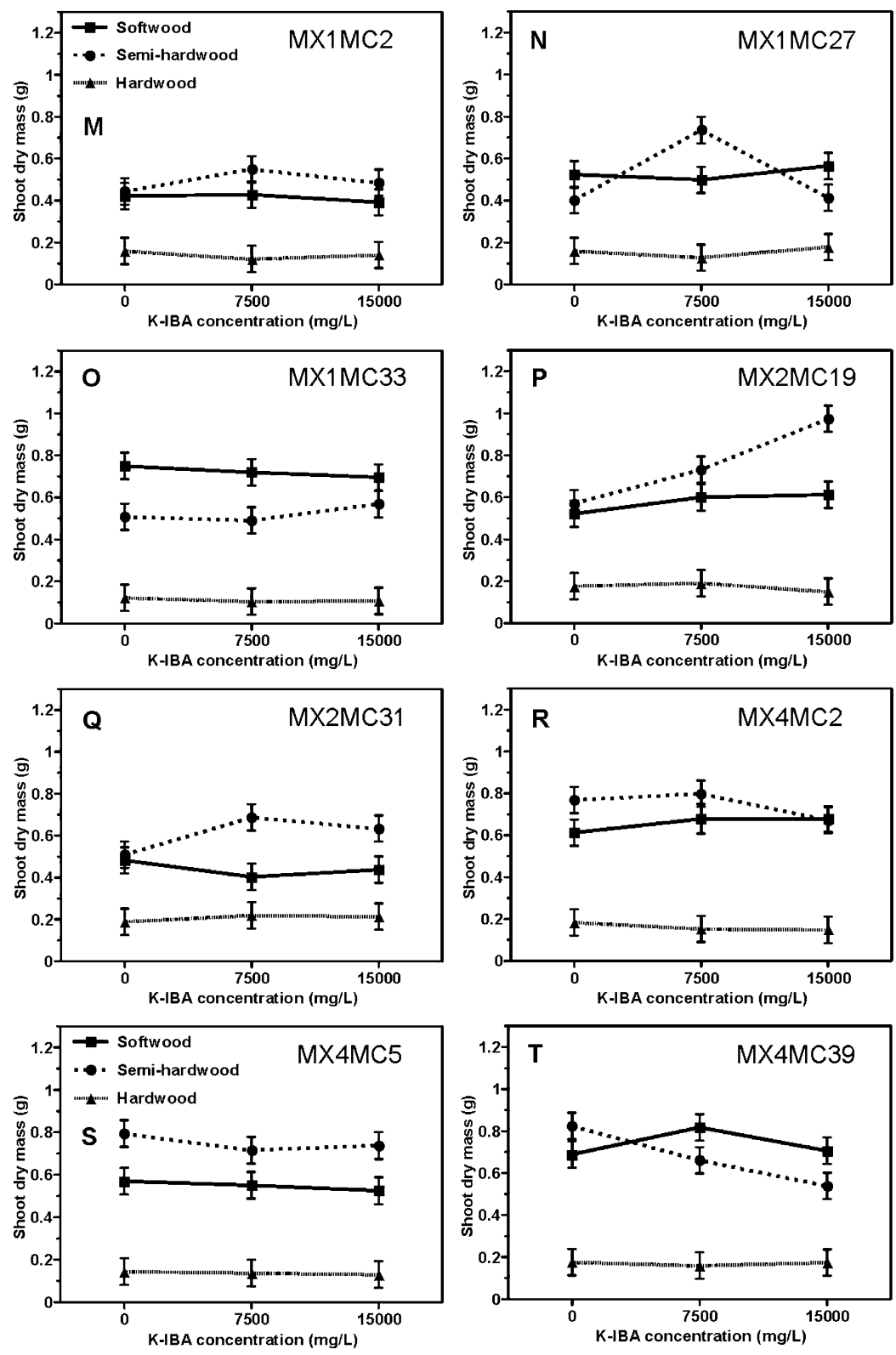

Fig. 8. (Continued)
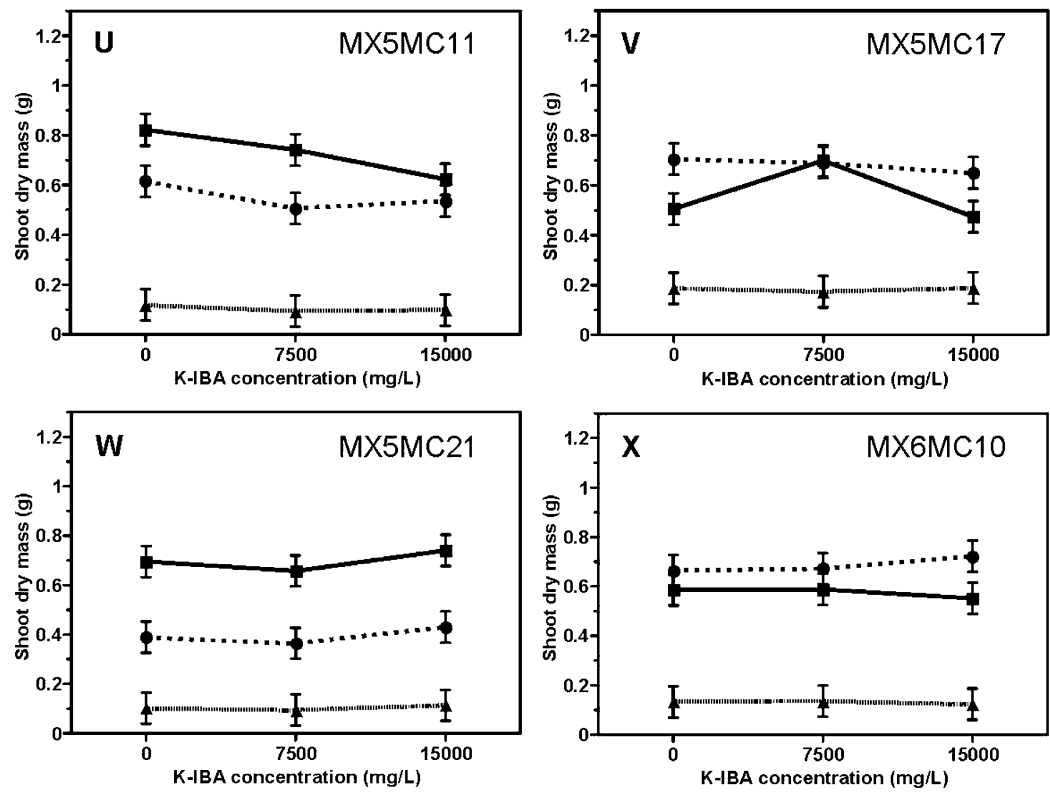
development appeared to be lacking (Fig. 8) and not related to adventitious root regeneration responses (Figs. 6 and 7).

Taxodium cuttings in this study generally rooted at a greater percentage and were higher in quality when collected as softwood cuttings from provenances in south Texas and Mexico and treated with either 7,500 or $15,000 \mathrm{mg} \cdot \mathrm{L}^{-1}$ K-IBA. Rooting quantity and quality from semihardwood cuttings were generally found to be great enough to warrant potential commercial propagation. Cuttings from the hardwood stage in this study rooted so poorly that without modification, the practice of taking hardwood cuttings of baldcypress is inadvisable at this time. Future work should focus on the improvement of hardwood cutting propagation. Bottom heating and photoperiod interruption are two treatments that should be taken into consideration. Techniques for prolonging the high rooting potential of desirable clones as ortets age are also needed. Although the clones from south Texas and Mexican provenances rooted at greater quantities and quality on the whole, the clone that performed best overall was TX8DC38, a central Texas clone.

\section{Literature Cited}

Arnold, M.A. 2008. Landscape plants for Texas and environs. 3rd Ed. Stipes Publ., Champaign, IL.

Copes, D.L. and W.K. Randall. 1993. Rooting baldcypress stem cuttings. Tree Planters Notes 44:125-127.

Denny, G.C. 2007. Evaluation of selected provenances of Taxodium distichum for drought, alkalinity and salinity tolerance. PhD diss., Dept. of Horticultural Sciences, Texas A\&M Univ., College Station, TX.

Denny, G.C. and M.A. Arnold. 2007. Taxonomy and nomenclature of baldcypress, pondcypress, and Montezuma cypress: One, two, or three species? HortTechnology 17:125-127.

Dirr, M.A. 2009. Manual of woody landscape plants: Their identification, ornamental characteristics, culture, propagation and uses. 6th Ed. Stipes Publ., Champaign, IL.

Foster, G.S., R.K. Campbell, and W.T. Adams. 1985. Clonal selection prospects in western hemlock combining rooting traits with juvenile height. Can. J. For. Res. 15:488-493.

Jackson, M.B. 1986. New root formation in plants and cuttings. Martinus Nijhoff Publ., Dordrecht, The Netherlands.

King, A.R. 2010. Vegetative propagation and topophytic responses of selected baldcypress clones. MS thesis, Dept. Hort. Sciences, Texas A\&M Univ., College Station, TX.

Pezeshki, S.R. and R.D. DeLaune. 1994. Rooting of baldcypress cuttings. New For. 8:381-386.

St. Hilaire, R. 2003. Propagation of Taxodium mucronatum from softwood cuttings. Desert Plants 19: 29-30.

Struve, D.K., J.T. Talbert, and S.E. McKeand. 1984. Growth of rooted cuttings and seedlings in a 40-year-old plantation of eastern white pine. Can. J. For. Res. 14:462-464.

Thomsen, A. 1978. Propagation of conifers by cuttings and grafting. Intl. Plant Propagators Soc. Combined Proc. 28:215-220.

Zhou, L. 2005. Salt tolerance, propagation and provenance evalution of Taxodium as a landscape and coastal wetland tree. MS thesis, Dept. of Horticulture, Stephen F. Austin State Univ., Nacogdoches, TX. 